\title{
LIDAR AND PHOTOGRAMMETRY APPROACHES FOR MONITORING LAND SURFACE MORPHOLOGY IN EPHEMERAL GULLY SYSTEM
}

\author{
Ximeng Xu, Qiuhong Tang* \\ Key Laboratory of Water Cycle and Related Land Surface Processes, Institute of Geographic Sciences and Natural Resources \\ Research, Chinese Academy of Sciences, Beijing 100101, PR China - (xuxm, tangqh)@igsnrr.ac.cn
}

KEY WORDS: Point cloud, Laser scanning, Morphology dynamics, Cross section, Hilly-gully region, Headcuts

\begin{abstract}
:
LIDAR and photogrammetry techniques were used to quantify the land surface morphology dynamics of ephemeral gully system based on the field investigation. LIDAR monitoring results showed that ephemeral gully occurred in the same location on the slope surface after every rainy season in the ephemeral gully system, then lateral topsoil was tilled and brought into the ephemeral gully channel, inducing $2 \mathrm{~cm}$ decrease around channel before rainy season of next year, which make it a cycle of erosion-tillage-erosion. During this process, imbricated landform was formed in ephemeral gully system. The photogrammetry monitoring results showed that most drop-sills distances in ephemeral gully channel were in 10 to $25 \mathrm{~cm}$, while slope gradients were among $15^{\circ}$ to $40^{\circ}$. The drop-sills distance and slope gradient showed negative exponent relationship. The results of this study showed that LIDAR technology can quickly acquire the topographic characteristics of the whole ephemeral gully system, while photogrammetry method could quickly acquire detailed morphology in ephemeral gully channel.
\end{abstract}

\section{INTRODUCTION}

\subsection{Ephemeral gully erosion}

Ephemeral gully erosion is the most important erosion type in the loess hilly-gully region. Ephemeral gully is a connecting link between rills and gully. The distribution area of ephemeral gully erosion occupied $35 \%$ of total area and ephemeral gully erosion amount contributed $35 \%-70 \%$ of total soil erosion amount (Zhu, 1956; Zhang, 1991). Among these decades, understandings about the ephemeral gully erosion has been greatly improved (Capra \& La Spada, 2015; Daggupati et al., 2014), but as the restrictions of long-term field monitoring data and monitoring technology, ephemeral gully morphology and dynamic process monitoring researches were still lacking.

\subsection{Traditional methods}

Traditional ephemeral gully morphology monitoring methods included volume replacement method, ruler method and needle plate method (Capra et al., 2009). The accuracy of volume replacement method was high but the time and labour costs were also high (Dong et al., 2015). Ephemeral gully monitoring method with a ruler could acquire the length, width and depth, but the whole picture of ephemeral gully catchment could not be drawn, ephemeral gully cross section was able not able to be determined. Needle plate method could acquire the cross section but with difficulty of accurately measure the morphology of ephemeral gully channel and catchment (Casalí et al., 2006).

\subsection{Modern monitoring method}

As the development of modern monitoring method, high accuracy differential GPS, 3-D laser scanning technology and stereo photogrammetry survey provided better monitoring resolutions for high-accuracy ephemeral gully monitoring.
RTK-GPS was used to quantify the morphology and spatial distribution of 49 ephemeral gullies on the Loess Plateau, relationships between upslope drainage area and slope gradient features of ephemeral gullies were quantified (Cheng et al., 2007), but ephemeral gully channel and cross section were not studied yet. Wu et al. (2018) utilized the 3D laser scanning technology monitoring the active stage gully morphology at the field conditions, their results showed that the monitoring accuracy was acceptable, suggesting that 3D laser scanning technology offers a promising method to study large-scale ephemeral gully morphology. Wells et al. (2009) established the photogrammetry methods of measuring small-scale ephemeral gully channels at both laboratory and field conditions, which make it possible for quick monitoring ephemeral gully channel morphology at field observation. This paper quantified the land surface morphology dynamics in ephemeral gully systems on the natural slopes under the natural rainfall conditions, based on the LiDAR and photogrammetry method. The results could provide the scientific bases for ephemeral gully erosion control and prediction model establishments.

\section{STUDY AREA AND METHOD}

\subsection{Field Station and Study Area}

Field investigation station was in the Wayaogou watershed, a branch of Yellow River located in the Fuxian County of Shaanxi Province (Figure 1). The landscape belongs to the loess hilly-gully region. The elevation varied from $920 \mathrm{~m}$ to $1683 \mathrm{~m}$, and the gully density of this area is $4.5 \mathrm{~km} / \mathrm{km}^{2}$. Annual precipitation was $576.7 \mathrm{~mm}$, which is concentrated in July, August and September. Sand particle occupied 6.7\%, while silt and clay particles occupied $71.7 \%$ and $21.2 \%$, respectively.

In 1989, to understand the human accelerated erosion in Ziwuling secondary forest induced by deforestation, several

\footnotetext{
* Corresponding author: Qiuhong Tang (tangqh@ihsnrr.ac.cn)
} 
natural runoff plots were constructed. After placing tillage practice of more than 20 years, the soil structure and physical properties was nearly same with the local farmland. Three ephemeral gully catchments were established with different area, upslope drainage area and slope conditions. During the monitoring years, traditional tillage method was applied before rainy season, tillage depth was $20 \mathrm{~cm}$, during the monitoring rainy season (April to October), the plot was kept as bare and fallow (Han et al., 2016).

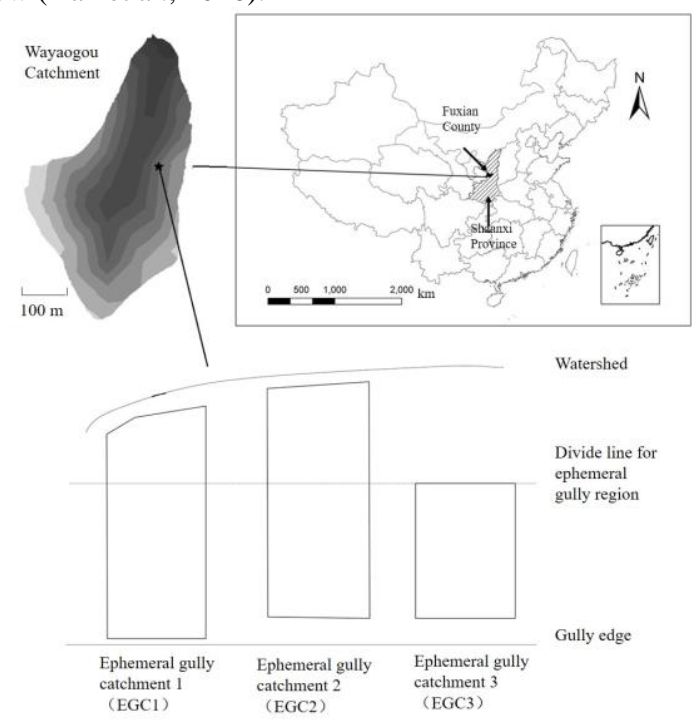

Figure 1 Location map of Wayaogou catchment and ephemeral gully catchments

The basic topographic features deciding the morphology of ephemeral gully were shown in Table 1.

\begin{tabular}{|l|c|c|c|c|c|}
\hline Tags & $\begin{array}{c}\text { Catchment } \\
\text { Area }\left(\mathrm{m}^{2}\right)\end{array}$ & $\begin{array}{c}\text { Upslope } \\
\text { drainage } \\
\text { area } \\
\left(\mathrm{m}^{2}\right)\end{array}$ & $\begin{array}{c}\text { Slope } \\
\left({ }^{\circ}\right)\end{array}$ & $\begin{array}{c}\text { Average } \\
\text { length } \\
(\mathrm{m})\end{array}$ & $\begin{array}{c}\text { Average } \\
\text { width } \\
(\mathrm{m})\end{array}$ \\
\hline EGC1 & 1012 & 362 & $11 \sim 32$ & 84.4 & 12.0 \\
EGC2 & 995 & 488 & $5 \sim 35$ & 73.0 & 13.6 \\
EGC3 & 424 & 188 & $26 \sim 35$ & 36.0 & 11.8 \\
\hline
\end{tabular}

Table 1. Topographic characteristics of three ephemeral gully catchments

\subsection{LIDAR}

A terrestrial laser scanner (Lecia Scanstation 2) was used to measuring land surface morphology changes in ephemeral gully systems. The scanner acquires the position of the target point by receiving the laser back to the scanner, then the coordinate value was confirmed by equation 1 (Figure 2 ).

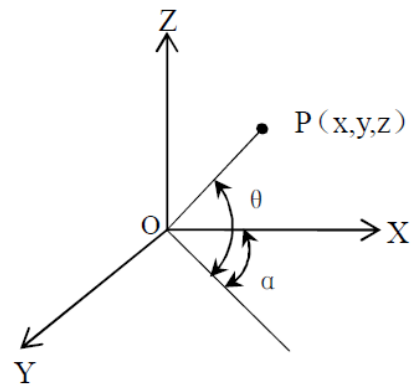

Figure 2 Three-dimension coordinate system

$$
\begin{aligned}
& \mathrm{x}=\mathrm{S} \cos \theta \cos \alpha \\
& \mathrm{y}=\mathrm{S} \cos \theta \sin \alpha \\
& \mathrm{z}=\mathrm{S} \sin \theta
\end{aligned}
$$

where $S=$ distance between target point and scanner $\mathrm{x}, \mathrm{y}, \mathrm{z}=$ coordinate value $\alpha=$ horizon scanning angle $\theta=$ vertical scanning angle

As the slope conditions varied greatly from upslope to downslope in an ephemeral gully system (Table 1), 3D laser scanning could not acquire the topographic features of the whole ephemeral gully catchment, thus, when conducting the scanning process, several scan stations should be included. Figure 3 shows the 5 scan stations during the monitoring process in EGC2.

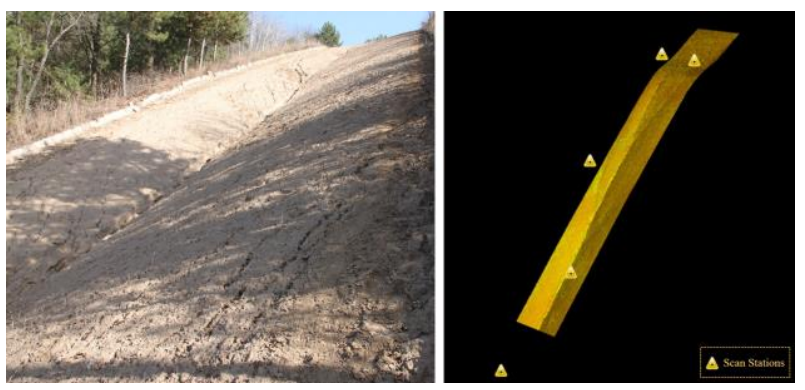

Figure 3 Five monitoring stations

To promise the connection processes of different point cloud datasets from different scan stations, four fixed targets were also settled around the ephemeral gully catchment and at least three of them can be saw in each scan. Scan density was set to $1 \mathrm{~cm}$, and point cloud date was pre-analysed in Cyclone 6.0 software, then transferred to ArcGIS 10.4 to get further analysis.

\subsection{Photogrammetry}

Gully sidewall may shelter the gully bottom topographic features during LiDAR monitoring, photogrammetry method was used to cover the shortage of LiDAR method. During the monitoring, ten targets were first settled around the channel, then cameral (Canon EOS 5D Mark II) was set to the manual mode, aperture f/2.8, ISO 250, and shutter speed 1/20 s. Automatic mode was used first to confirm suitable focal length, and then switched to manual mode. During taking pictures, focal length and cover areas of every two pictures were kept same. Pictures were then transferred in to the Agisoft Photoscan Professional 1.2.4 software (Agisoft LLC, St. Petersburg, Russia). After image correction and mosaic, point clouds were generated and imported into ArcGIS 10.4, the resolution of DEM is $1 \mathrm{~cm}$. 3D model of drop-sill in ephemeral gully channel was established and the drop-sill morphology was finally measured (Figure 4). 


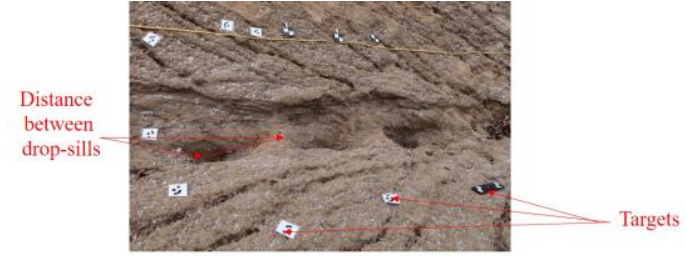

a. Photos of ephemeral gully channel from different viewpoints
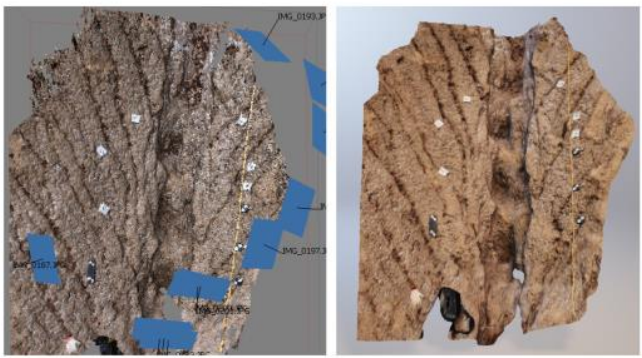

b. High density point clouds data $\quad$ c. 3D model of ephemeral gully channel

Figure 4 Ephemeral gully channel measured by photogrammetry

\section{RESULTS AND DISSCUSSIONS}

\subsection{Ephemeral gully morphology dynamics}

Figure 5 shows the variations of ephemeral gully length and cross section areas during the monitoring years.
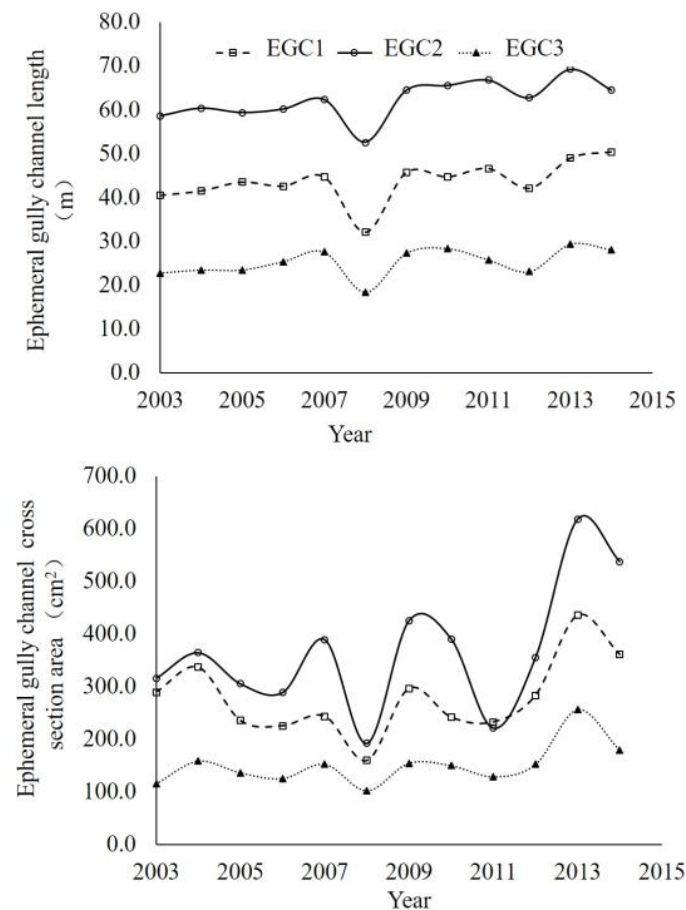

Figure 5 EG length and cross section variations

Ephemeral gully length and cross section area are important morphological characteristics which can also be used to show the soil erosion from ephemeral gully system. The results showed that, compared the ephemeral gully length in 2003, the length increased $12 \%$ to $30 \%$ at 2015 which illustrate the growth of ephemeral gully under natural rainfall and runoff events. The cross-section area in 2015 was also $23 \%$ to $65 \%$ higher than that in 2003. The comparison of the morphological characteristics in different ephemeral gully systems showed that the ephemeral gully length and cross section area were both largest in EGC2, which demonstrated the importance of upslope drainage area.

There are also some extreme values of ephemeral gully length and cross-section areas revealed in 2013, which correspond well to the extreme rainfall events with $131.0 \mathrm{~mm}$ rainfall happed in $21^{\text {st }}$ of July in that year.

Ephemeral gully morphology varied during the cycle of rain and tillage, after rainy season ephemeral gully channel width and depth were increased, rill network developed on two side slops of ephemeral gully channel; at next spring, horizon tillage would cover the ephemeral gully channel and rill network, only swale topographic was left on the slope surface; then, after the concentrated flow of next rainy season, ephemeral gully channel developed at the same place.

After the rainy season of 2013, ephemeral gully channel width and depth at $40 \mathrm{~m}$ of slope length was $41 \mathrm{~cm}$ and $18 \mathrm{~cm}$ respectively. At Apr. 2014 after horizon tillage, ephemeral gully channel was covered and lateral side-slopes height was decreased $2 \mathrm{~cm}$ averagely. After rainy season of 2014, ephemeral gully channel reoccurred the same place of slope, ephemeral gully channel width and depth was $32 \mathrm{~cm}$ and $16 \mathrm{~cm}$ respectively. At Apr. 2015 after horizon tillage, ephemeral gully channel was covered again and side slopes height was decreased about another $2 \mathrm{~cm}$.

\subsection{Drop-sill morphology based on photogrammetry}

Ephemeral gully channel was the results of concentrated flow, energy emerge and consumption can be reflected on the dropsill morphology. Figure 6 shows a scheme of drop-sill chain in typical ephemeral gully channel.

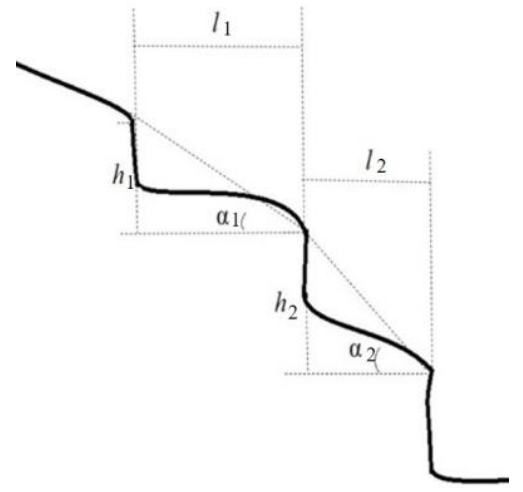

Figure 6 Schematic of drop-sill

Based on the established 3D model of ephemeral gully channel by photogrammetry approach, the drop-sill distance and slope were measured, then flow energy can be calculated as:

$E_{p}=\rho q g h=\rho q g l(\tan \alpha)$

$E_{v}=\rho q V^{2} / 2$

where $\quad E_{p}=$ potential energy of flow

$\rho=$ water density

$q=$ unit flow discharge

$g=$ gravity acceleration

$\rho=$ water density

$l=$ distance between drop-sills or drop-sill length

$\alpha=$ gradient of the drop-sill

$E_{v}=$ kinetic energy of flow

$V=$ flow velocity 
In the concentrated flow erosion process, flow potential energy was high first and then transferred to flow kinetic energy which represented by higher flow velocity. Higher flow velocity resulted in higher soil detachment rate and transport rate which caused more soil erosion in the ephemeral gully channel. At the headcut position, a sudden change of flow energy from potential energy to kinetic energy happened as the flow experienced a sudden height decrease. Then, when flow kinetic energy was consumed for detaching and transporting soil particles in the ephemeral gully channel.

At the end of rainy season of 2014, the drop-sill chains were measured and summarised. The frequency of distance between drop-sills $(l)$ and slope gradient $(\alpha)$ were listed in the Figure 7. The drop-sill distance mainly distributed in 10 to $35 \mathrm{~cm}$, and $70 \%$ of drop-sill distance were in 10 to $25 \mathrm{~cm}$. Compared with the drop-sill distance in the rill channel, distances in the ephemeral gully channel were much smaller which illustrated the larger flow energy in ephemeral gully channel. Slope gradient in the drop-sill position were distributed from $15^{\circ}$ to $40^{\circ}$, which was similar with former result (Zhang et al., 1991).

With the increase of slope gradient, drop-sill distance was decreased (Xu et al., 2019). An exponent relationship between drop-sill distance and slope gradient was established as $l$ $=6.731 \mathrm{e}^{-0.049 \alpha}$ and $R^{2}$ was 0.9032 (Figure 7). When slope gradient was small, longer drop-sill distance was required to get enough flow energy; on the contrary, when slope gradient was large, small drop-sill distance was required.

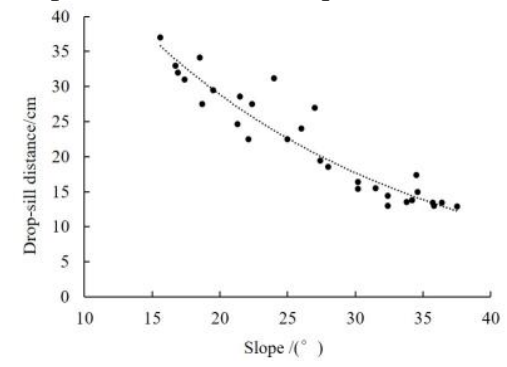

Figure 7 Relationship between drop-sill distance and slope in ephemeral gully channel (Xu et al., 2019)

\subsection{Comparison of two methods}

LiDAR technology can be used quickly acquire the topographic characteristics of the whole ephemeral gully catchment, but at some positions like gully bottom, this technology cannot get high density point cloud because of long scanning distance and gully sidewall shelter. While photogrammetry method could make up this disadvantage and quickly acquire detailed ephemeral gully channel morphology.

\section{CONCLUSIONS}

The LIDAR monitoring results showed that tillage in spring brings the lateral topsoil into the ephemeral gully channel which induced $2 \mathrm{~cm}$ decrement of soil layer around the channel. Dropsills chain structure in ephemeral gully channel reflected flow energy transfer and consumption process. The photogrammetry monitoring results showed that $70 \%$ of drop-sills distances were in 10 to $25 \mathrm{~cm}$, while slope gradients in $15^{\circ}$ to $40^{\circ}$. The dropsills distance and slope gradient showed negative exponent relationship. LIDAR technology can quickly acquire the topographic characteristics of the whole ephemeral gully system; however, it may not be able to while photogrammetry method could quickly acquire detailed ephemeral gully channel morphology. The results of this study improved understanding of land surface morphology variations in ephemeral gully system which could help erosion control practices.

\section{ACKNOWLEDGEMENTS}

This research is supported by the National Natural Science Foundation of China (41790424), the Strategic Priority Research Program of Chinese Academy of Sciences (XDA20060402) and International Partnership Program of Chinese Academy of Sciences (131A11KYSB20170113).

\section{REFERENCES}

Capra, A., La Spada, C. Medium-term evolution of some ephemeral gullies in Sicily (Italy). Soil and Tillage Research, 2015, 154: 34-43.

Capra, A., Porto, P., Scicolone, B. 2009. Relationships between rainfall characteristics and ephemeral gully erosion in a cultivated catchment in Sicily (Italy). Soil and Tillage Research, 105(1), 77-87.

Casalí, J., Loizu, J., Campo, M. A., De Santisteban, L. M., Álvarez-Mozos, J. 2006. Accuracy of methods for field assessment of rill and ephemeral gully erosion. Catena, 67(2), 128-138.

Cheng, H., Zou, X., Wu, Y., Zhang, C., Zheng, Q., Jiang, Z. 2007. Morphology parameters of ephemeral gully in characteristics hillslopes on the Loess Plateau of China. Soil and Tillage Research, 94(1):4-14.

Daggupati, P., Sheshukov, A. Y., Douglas-Mankin, K. R. Evaluating ephemeral gullies with a process-based topographic index model. Catena, 2014,113:177-186.

Dong, Y., Li, F., Zhang, Q., Lei, T. 2015. Determining ephemeral gully erosion process with the volume replacement method. Catena, 131:119-124.

Han, Y., Zheng, F. L., Xu, X. M. 2017. Effects of rainfall regime and its character indices on soil loss at loessial hillslope with ephemeral gully. Journal of Mountain Science, 14(3): 527538.

Wells, R., Momm, H., Bennett, S., Gesch, K., Dabney, S., Cruse, R., Wilson, G. 2016. A measurement method for rill and ephemeral gully erosion assessments. Soil Science Society of America Journal, 80(1), 203-214.

Wu, H., Xu X., Zheng F., Qin, C., He, X. 2018. Gully morphological characteristics in the loess hilly-gully region based on 3D laser scanning technique. Earth Surface Processes and Landforms, 43, 1701-1710.

Xu, X., Zheng, F., Qin, C., Han, Y. 2019. Dynamic monitorin of ephemeral gully development and its morphology quantification in Loess Hilly-gully region. Transactions of the Chinese Society of Agricultural Machinery, 50(4), 274-282.

Zhang, K. 1991. Study on the effect of shallow gully development on soil erosion. Soil and Water Conservation in China, 4, 17-19. 
The International Archives of the Photogrammetry, Remote Sensing and Spatial Information Sciences, Volume XLII-4/W18, 2019

GeoSpatial Conference 2019 - Joint Conferences of SMPR and GI Research, 12-14 October 2019, Karaj, Iran

Zhu, X. 1956. Classification on the soil erosion in the Loess region. Acta Pedologica Sinica, 2, 99-115. 